\title{
Improvisation as a research methodology: Exploring links between filmmakers' practice and traditions of enquiry across the academy
}

Article

Accepted Version

Lees, D. (2019) Improvisation as a research methodology: Exploring links between filmmakers' practice and traditions of enquiry across the academy. Media Practice and Education, 20 (2). pp. 134-146. ISSN 2574-1136 doi:

https://doi.org/10.1080/25741136.2019.1605675 Available at https://centaur.reading.ac.uk/100691/

It is advisable to refer to the publisher's version if you intend to cite from the work. See Guidance on citing.

Published version at: https://www.tandfonline.com/doi/abs/10.1080/25741136.2019.1605675?journalCode=rimp21

To link to this article DOI: http://dx.doi.org/10.1080/25741136.2019.1605675

Publisher: Routledge

All outputs in CentAUR are protected by Intellectual Property Rights law, including copyright law. Copyright and IPR is retained by the creators or other copyright holders. Terms and conditions for use of this material are defined in the End User Agreement. 


\section{CentAUR}

Central Archive at the University of Reading

Reading's research outputs online 


\title{
Improvisation as a research methodology: exploring links between filmmakers' practice and traditions of enquiry across the academy.
}

Article developed from a paper delivered to 'Contexts for Film Practice', the Media Practice and Education / MeCCSA Practice Network Annual Symposium, University of Lincoln, June 2018.

Dominic Lees

Department of Film and Journalism, University of the West of England, Bristol, UK. Corresponding author. Email: dominic.lees@uwe.ac.uk

\begin{abstract}
This article concentrates on one form of creative practice, improvisation, considering how it has been used as an experimental method within filmmaking as well as in research enquiry. Drawing on my professional experience in the field of narrative fiction filmmaking, as well as interviews with film professionals, I show how a close examination of improvising processes opens up illuminating points of comparison with research methodologies across the academy. This article is an interdisciplinary review, drawing together ideas about improvisation beyond film, looking broadly across the creative arts and most pointedly, drawing an unexpected link between practice research in film and the traditions of laboratory research methodologies within Social Psychology.

KEYWORDS

Improvisation; research methodology; practice research; The Stanford Prison Experiment; Performance-Centred Mode.
\end{abstract}

Improvisation in creative practice is analogous to the processes of knowledge production in academic research. By definition, improvisation involves the discovery of creative outcomes; traditions that have used it extensively, such as theatre and music, engage in this experimental process with the intention of generating a performance that may either have immediate significance to a present audience, or as a studio practice designed to accumulate ideas in the devising of a future performance. For the performer, improvisation is a process of exploration. The creative goal of the exercise may be quite loosely defined, but the revelations achieved through improvisation are intended to have artistic impact. The obvious similarities with the process of academic research have stimulated a field of studies ${ }^{1}$ and detailed scholarly attention, primarily in musicology and performance. In this article, I will present an overview of how improvisation is studied in a range of fields, before looking in detail at how certain filmmakers have deployed it as a creative practice. The final section presents surprising similarities between the improvisation

1 The University of Guelph in Ontario, Canada, has founded the International Institute for Critical Studies in Improvisation (IICPI) 
techniques in film and the research methodologies used in laboratory experiments in Social Psychology. This link allows us to reflect and compare certain practice research methodologies in filmmaking with older and more established areas of academic research.

Improvisation is a concept that some writers have shown reluctance to define, with Lewis and Piekut deliberately making 'no explicit attempt to negotiate a single overarching definition of improvisation' $(2016,3)$ in their key work on the subject, The Oxford Handbook of Critical Improvisational Studies. The idea of improvisation is applied very broadly across subject areas, with linguistic interaction seen as the originating experience that informs our understanding of improvisation in creative practice. The detailed research on improvisation in psycholinguistics brings Lewis and Piekut closer to a definition: from the writer Keith Sawyer they find that,

the key characteristics of improvisation include:

- unpredictable outcome, rather than a scripted, known endpoint

- moment-to-moment contingency: the next dialogue turn depends on the one just before

- open to collaboration

- an oral performance, not a written product

- embedded in the social context of the performance (Lewis and Piekut 2002, 231)

Many of Sawyer's characteristics are transferable into other forms of improvisation, with the exclusion of the linguistic characteristic of a non-written outcome. In film, literature, and in many cases of musical improvisation, the practice leads towards a written or recorded text. Writers in the beatnik era famously adopted the practice, seeking to develop a method to produce unpremeditated literary work. In his 'essentials of spontaneous prose', Jack Kerouac outlined his method:

following free deviation (association) of mind into limitless blow-on-subject seas of thought, swimming in sea of English with no discipline other than rhythms of rhetorical exhalation and expostulated statement, like a fist coming down on a table with each complete utterance, bang! (the space dash) (quoted in Heble 2015, 207)

Kerouac only made sketches towards a series of governing principles behind literary improvisation, but he was aware that the process was an ordered practice within which the writer explored unpredicted outcomes. This later became a concept developed by theorists of improvisation in both music and literature. Rob Wallace proposes that the process is not one of complete spontaneity, but remains a systematised form of creative production. Of other literary figures using improvisation, he writes,

Hughes writing blues and jazz-influenced verse in the moment, [...] and Stevens composing poems to the rhythms of his walking and breathing. The work of all of these poets also exhibits the method of improvisation. (Wallace 2015, 197) 
Literary improvisation, therefore, is understood as a loose collection of creative processes that a writer can choose to adopt if the intention is to deliberately seek an 'unpredictable outcome'. It is interesting to see similar ideas discussed within the discipline of screenwriting studies. This literary form has been dominated by rulesbased systems of writing, with a formula described by Ian Macdonald:

Usually referred to as 'craft skills', the doxa is well documented in manuals and underpinned by courses for budding screenwriters, and by the UK's training agency for screenwriting, Skillset. [...] The point is that they all offer a consistent normative framework representing a specific approach to storytelling on screen. (2010, 48-9)

However, researchers in the field have explored alternative creative practices that break with the regimented screenwriting traditions, towards a more improvisatory method. Siri Senje (2017) has written eloquently about her own screenwriting process, in a research project in which she trialled and compared two approaches. First, she wrote a script following the familiar structured stages of Outline, Treatment and First Draft. This she calls the Set Stage Chronology of Documents (SSCD), the established film industry procedure that requires the screenwriter to imagine in detail a script before its writing. Senje emphasises that,

This practice implies that one specific writing method is universal and deemphasizes such aspects of creativity as improvisation, free association and the accessing of subconscious resources - all widely assumed to be significant in creative work. $(2017,267)$

Next, she followed a freeform approach to screenwriting - a strategy that I would describe as a version of literary improvisation - and contrasted the creative outcomes with those she achieved when adopting the SSCD. Senje's outcome demonstrated that in forms of creative writing normally subject to rigid structures, improvisatory methods could represent a valuable alternative approach.

Music and theatre have the longest and richest histories of improvisation. Ethnomusicologists identify whole cultural traditions in which improvisation forms the basis for musical production. Early theoretical writing on musical improvisation began with Ernst Ferand's 1938 work, Die Improvisation in der Musik. The Czech writer Bruno Nettl dominated the field in the late twentieth century with major studies of the music of Native American cultures. More recently, musicologists have examined improvisation, how it is done and how it can be taught, at an impressive depth. Jeff Pressing (2001/2012) looks at improvisation in terms of physiology and neuropsychology, with detailed modelling of systems of learning and instruction.

It is theatre studies, however, that offers a natural bridge with filmmaking practice, as both art forms share a central concern with the director-actor relationship. Practitioner-theorists in the theatre conceptualise improvisation as linking back towards linguistic interaction. Hodgson and Richards write that,

Improvisation in drama aims to utilize the two elements of everyday life improvisation: the spontaneous response to the unfolding of an unexpected situation, and the ingenuity called on to deal with the situation; both of these 
in order to gain insight into problems presented. (Hodgson and Richards 1974, 2)

The latter statement, on gaining insights, hints at the potential of improvisation as a research methodology. However, as Gary Cassidy has pointed out (2018), much of the literature on improvisation within theatre studies has focussed on its use in developing performance. His research has been on its use in devising the script, with a detailed study of the director-playwright Anthony Neilson. As an established actor from the 'In Yer Face' theatre movement, Cassidy was able to gain access to Neilson throughout his process of devising a new theatre work. He recounts how the director is reliant on his ensemble to deliver the prompts for his scriptwriting, saying to them,

'I just want to see what might be the start of something [...] you'll feel like dicks but I just want to see what it looks like'. So, from this information, it can be discerned that Neilson has nothing concrete in mind regarding the outcome of the improvisation. Instead he is hoping that there may be something which prompts his imagination into generating an idea from which he can produce material. (Cassidy 2018, 14)

We will see how this use of improvisation to devise theatre pieces is carried into the creative practice of a particular group of independent filmmakers.

\section{IMPROVISATION IN FILMMAKING}

In narrative fiction film, directors who employ techniques of improvisation represent a small group, but their practice is one of the most distinct alternative creative approaches to filmmaking. In the field of ethnographic filmmaking, Jean Rouch also adopted these techniques, as discussed by Johannes Sjöberg in JMP (2008), but for this article, I will limit myself to an analysis of the creative practice of independent feature film directors. Here, a number of directors draw on theatrical traditions of improvisation, using the process to devise characters, performance styles and even the screenplay. My recent research has grouped such film directors into a 'PerformanceCentred Mode' of filmmaking practice. In developing the concept of this Mode, I have identified an approach to film directing that prioritises an engagement with actors above the many other creative considerations that are required of a director. This mode of practice is relatively rare: the common experience of screen actors with whom I have worked, and others that I have interviewed, is of minimal collaborative attention on set from the film or TV directors who have cast them. This is in stark comparison to actors' experience of work on stage, where weeks of intensive collaboration between director and cast lead to the creation of the production. When moving into screen acting, actors find that they must usually fend for themselves through all the complex considerations around the creation of a screen performance.

For directors in the 'Performance-Centred Mode', there is a thorough rearrangement of the creative emphasis within fiction filmmaking, with the director-actor collaboration elevated to a level of intensity unseen in the practice of the vast majority of filmmakers. Directors who share this emphasis are international and identifiable by their approach to film practice. Here are some leading examples: 
2. Australia: David Marchand

3. Denmark: Annette K. Olesen

4. France: Blandine Lenoir

5. United Kingdom: Mike Leigh, Sally Potter

6. United States: John Cassavetes, Jake Doremus

\section{MIKE LEIGH}

The aspect of practice that unifies these diverse directors is the adoption of improvisation within their filmmaking process. For some, this is used as a version of devising. To take Mike Leigh as an example: he begins work on a new film without any clarity as to the final script outcome. He has emphasised this point in interview:

People say to me 'Do you know the story (when you begin)? Do you know the end? Do you know the narrative?' The answer to those questions is 'No, No and No'. (Carney 2000, 6)

Mainstream film practice gives the screenwriter the primary role of creating characters and story; the director and actors then interpret and develop these characters during preproduction and the shoot. Not so in the Performance-Centred Mode. Although Mike Leigh gets the credit as the writer of his films, he has altered the balance of creative responsibility in his filmmaking process: during the months of collaboration with his actors during rehearsal, in which he improvises and devises with his cast, he offers his performers a central role. Elizabeth Berrington has created characters in four of Mike Leigh's films: Naked (1993), Secrets and Lies (1996), Vera Drake (2004) and Mr.Turner (2014). She described to me the experience of devising a character with Mike Leigh:

First of all you start talking about real characters that you've met. They're not family members and they're not actresses, they are people your own age, so right from the off you are going to be exploring something that is very close to you. [...] So you agree on your chosen character and they then become this blueprint for this brand new invention that you are going to make, and you go on this very slow journey building this reality around somebody. ${ }^{3}$

This careful collaborative process begins with weeks of one-to-one work between Leigh and each individual actor in the ensemble. This empowers the actors in their roles before they move into the ensemble improvisation stage. Here, the characters' dialogue is generated by the actors themselves - a frequent characteristic of the creative process within the Performance-Centred Mode. Lesley Manville, who has worked with Leigh from High Hopes (1988) to Mr Turner (2014), described the process of originating dialogue in an interview with author Amy Raphael:

'There is no script', Manville confirms [...] As the character's history evolves, they develop a voice: 'Because you've created such a thorough background for them, the process of dialogue forming and emotional exchanges taking place look after themselves'. (2008, xii)

\footnotetext{
${ }^{3}$ Extract from interview with Dominic Lees, $5^{\text {th }}$ December 2016
} 
At the end of months of improvisation with his ensemble, Mike Leigh collates a form of screenplay. He provides a very precise description of his writing role:

Just before shooting begins, I write a scenario - a shooting script, I call it. It's a very short thing. Merely a structure. No dialogue. No detailed descriptions. From my point of view, the whole operation is designed to make it possible for me to be genuinely spontaneous and creative on the shoot. (Raphael 2008, 30)

Leigh's intention is clearly to allow the culture of improvisation developed during preproduction to extend into the film shoot itself. For a respected cinematic auteur, Mike Leigh is fascinating in his use of a creative practice that shifts preconceptions about film authorship - in terms of the screenplay, he shares his authorial role with his ensemble of actors.

\section{ROBERT MARCHAND}

The Australian author and filmmaker, Robert Marchand, has developed what he describes as 'the Character-Based Improvisation (CBI) process' $(2015,38)$, which he has used in his work making TV movies (Come in Spinner, 1990; Singapore Sling, 1993; Marriage Acts, 2000). He has referred to Mike Leigh as a significant influence when developing CBI, indicating an important transfer of ideas and performancecentred filmmaking practice across English-language screen production. Similarly to Leigh's process, Marchand describes how Character-Based Improvisation 'starts from character independently from narrative; the focus on the detail of the character in all its potential mundanity' $(2015,38)$. Again, it is a practice in which character is developed before story.

Marchand positions his CBI method against the dominant film practice approach to developing characters:

CBI Process occupies a niche in screen drama practice and is considered an alternative to the conventional method of a script or screenplay which actors use as a basis for their performances. (Marchand 2018)

The creative focus is on the collaboration between director and actor, demanding the filmmaker's prioritising of this relationship and locating this approach firmly within the Performance-Centred Mode of filmmaking. Marchand's method is divided into three phases:

1. The construction of character

2. The construction of relationships

3. The construction of drama

This process involves multiple layers of improvisations:

The character acquires 'history', not just by an accumulation of facts, but by an accretion of experiences. Over a period of several weeks the actor frequently goes into character, making it a habitual, commonplace occurrence; he or she may be in character for lengthy periods of time and will investigate a 
range of personal, domestic, workplace and social situations. As a result, the character evolves and 'matures'. (ibid.)

Marchand gives particular stress to the imaginative construction of 'unseen' relationships from a character's backstory. The CBI-trained actor will thus work to generate not just their own character, but other detailed characters from their past, such as schoolteachers or family. He also puts special emphasis on a character's worklife:

Work experience, the workplace of the character past and present, effectively the character's C.V., is also investigated thoroughly. Throughout, this work puts its focus on the believable, sometimes mundane, every-day activities of the character. (ibid.)

Marchand is clear about the benefits of his performance-centred practice to both the spectator and the filmmakers. The CBI process serves to,

invite the audience to consume the fictional character as if it had identity, but also encourage the director and actor (each individually) to proceed as though the characters they create have lived identities. (Marchand 2015, 38)

For Marchand, his work within a Performance-Centred Mode of filmmaking is a strategy to create believability in his film characters, an emotional and psychological authenticity that enables the illusion of 'identity'.

\section{FEDERICO GODFRID}

Federico Godfrid is an Argentinian director responsible for two feature films, $L a$ Tigra, Chaco (2008) and Pinamar (2016). His earlier career was in fringe theatre, in which he adopted semi-devised processes of creating plays, a background which reflects that of Mike Leigh. Both Godfrid's films are low-budget productions made using practices developed by the director in order to integrate his performers closely in the process of creating these movies.

Reflecting the creative process of Mike Leigh, in Godfrid's work the rehearsal stage of developing performance becomes highly extended. However, he chooses a different starting point: whereas Leigh commences work with his actors before he has any sense of the characters and narrative of his forthcoming film, Godfrid develops a rough draft screenplay before casting his actors. The innovation introduced by Godfrid to the director-actor collaboration is what he calls the 'Journey'. The physical location of his films is of particular significance to Godfrid; he sources the shooting locations during the early drafting of his script. The locations are the director's primary resources before embarking on a collaboration with his actors. Godfrid has conceived a form of project manifesto for the creative process which involves both himself and his cast: he calls this 'The Journey as Emotional Catalyst: To generate a fiction film from the collaborative work between the director and actors travelling to a place away from their everyday life'. In the 'Journey', Godfrid initiates a careful process in which he will develop the structure of relationships between actors, characters and director. 
Spending time in a filming location is, for Godfrid, essential to an actor's preparation: the performer's response to the social and physical location of the film will support the process of creating a fully-formed screen character.

The movie will be shooting in a new space, so the first thing is to perceive the new space and try to feel comfortable with it. Immerse yourself in the new context, in the new culture, and perceive what will happen to you in this place. $^{5}$

Godfrid is interested in the actors' sense of discovery in the location. I asked him if he rehearsed scenes for the film and his answer was revealing:

Yes, but only on the third day. The first two days we don't take the script. We wander, go bowling, drink some beers, don't act, try to perceive the others [local people]. The third day we start to read the script and try some scenes in the spaces. (ibid.)

The expectation that Godfrid makes is that the locations that he has chosen will have a profound impact on his performers: their responses to new environments will impact significantly on their creative decisions in developing their screen characters. He wants the actors to observe local people, to allow the specific characteristics of the social locus of the film to inform how their fictional character behaves. Most interestingly, Godfrid includes himself in this process of creative reaction to an environment: 'We wander, go bowling...' The journey is not just for the benefit of the performers, in order to help them to build unique characters, but also for him as the filmmaker. This is a significant extension of the Mike Leigh method, which demands research by the actors outside the rehearsal process, but without the presence of their director. Godfrid puts himself with the performers at every stage of the preproduction research process, so that the 'Journey' is an intimate experience of collective discovery.

The close quality of relationship that can be developed in such a collaborative process far exceeds that of conventional filmmaking. The way that Godfrid describes talking with his actors during the shoot is similar to that of a good and supportive friend:

I ask them, how do you feel it? And they tell me, but sometimes I feel that they are afraid, I have to say, 'Have confidence, it's okay just do it'. (ibid.)

Improvisation has proved itself to be a valuable creative tool within the PerformanceCentred Mode of filmmaking, however there must be a separate discussion over its efficacy as a practice research methodology within the academy. The nature of improvisation is that the final outcome cannot be predicted, so methodologically such practice cannot begin with a concrete hypothesis. In terms of the research paradigms outlined by Estelle Barrett and Barbara Bolt, the methodology can only fit within what these writers call 'Performative Research', which they describe as,

\footnotetext{
${ }^{5}$ Dominic Lees interview with Federico Godfrid, $18^{\text {th }}$ November 2015
} 
Expressed in non-numeric data, but in forms of symbolic data other than words in discursive text. These include material forms of practice, of still and moving images, of music and sound, of live action and digital code. (Barrett and Bolt 2010, 151)

Robin Nelson has discussed how such research must, by its nature, involve multiple questions, framed in an open manner:

artworks are often complex, multi-layered and resonant. Accordingly, there are several possible lines of research inquiry, some perhaps compositional, some technological, some involving performance qualities $[. .$.$] and others$ conceptual. (Nelson 2013, 27)

Improvisation fits into this form of creatively-driven enquiry, representing a methodology that involves risk and open experimentation. As a system of exploration, it is perfectly formed for a process of enquiry. This may explain why it has been deployed in academic research beyond the field of creative practice.

\section{IMPROVISATION IN SOCIAL PSYCHOLOGY}

In looking broadly at improvisation and its use in many fields of creativity and study, striking similarities emerge with the methodologies deployed in experimental research within social psychology. Scholars in this field have a long tradition of investigating the dynamics of human relations by building semi-real situations and asking their subjects to improvise their way through the scenario in the most natural way possible. Over more than a century of its development, the discipline has established carefully codified research methods. Hewstone and Stroebe describe two forms of experiment in social psychology:

the quasi experiment is one conducted in a natural, everyday life setting, over which the researcher has less than complete control [...] the realism of the setting is relatively high, the control relatively low.

The true randomized experiment, by contrast, is one in which the researcher has complete control over key features of the setting; however, this degree of control involves a loss of realism. (Hewstone and Stroebe 2001, 81)

In addition, what is termed a 'field experiment' is a true randomized experiment conducted in an everyday setting, a methodology that tries to combine the virtues of both approaches.

There is an awareness amongst social psychologists that their tradition of research experimentation is not just an academic exercise, but has links with creative performance. Hewstone and Stroebe note explicitly that the methodology bears parallels with the practice of making drama:

There is a sense in which the typical laboratory experiment is like staging a play, with the exception that the participants' lines are unscripted. $(2001,84)$

The term 'improvisation' is not used, but the authors are clearly describing just such a practice. Social psychologists regularly recruit non-actors, termed 'volunteers', to 
perform in controlled conditions. The experiments can involve a level of deception of the volunteers, and the creation of situations designed to surprise and challenge them. One of the most notable researchers in this tradition was Stanley Milgram, the Yale University social psychologist who, in the 1960s, conducted 'obedience experiments' that demonstrated how ordinary people, if subjected to the demands of a malevolent authority figure, would electrocute someone whom they believed to be a real subject of a scientific experiment. In this experiment, volunteers were carefully misled: they were told that they were taking part in an experiment looking at learning and discipline. Each volunteer was instructed to apply an electric shock to a learner on every occasion that he made an error, increasing the charge with each subsequent mistake. The learner was in fact an actor, who performed the escalating agonies with each fake electric shock, and finally feigned unconsciousness. Milgram was not the first to adopt such research methodologies - he commented that the practice dates back to the work of Boris Sidis in 1898. Muzafer Sherif had conducted well-known field experiments in 1953 and 1954, around the behaviour of young boys divided into rival 'tribes'. His much-publicised 'Robbers Cave Experiment' bears similarity with the themes of William Golding's 'Lord of the Flies' and helped develop an important understanding in psychology that is known as 'realistic group conflict theory'. However, Sherif's use of surprise and deception to guide his volunteers through the improvisation has been sharply criticised, most recently by the researcher Gina Perry (2018).

Filmmakers using improvisation have deployed similar strategies of surprise and deception, in order to stimulate natural, or unperformed reactions from their actors. Although film actors have a degree of collaborative control not enjoyed by the volunteer in a social psychology experiment, they are still subject to forms of manipulation designed to provoke their performance. During the production of Mike Leigh's Vera Drake (2004), the director never explained to his leading actor, Imelda Staunton, how the consequences of her character's work as a backstreet abortionist would play out. Staunton described to author Amy Raphael how the improvised scene in the family flat developed, and her reactions:

'When I heard the knock at the door, I assumed it was Ruth Sheen's character Lily. When Vera's husband Stan said it was the police, I had a sudden pain in my chest. I felt as though I was going to have a heart attack'. (Raphael 2008, $\mathrm{xv}$ )

Furthermore, the ensemble cast playing Vera's family, including Phil Davis who played Stan, were equally unprepared for the scenario that Mike Leigh had prepared.

During that rehearsal, a police station set was hastily built downstairs. Phil Davis: 'When we got down to the main hall, the whole place had been transformed into a police station. All these actors were being policemen and women, some doing tasks unrelated to us. It was fantastic.' (ibid.)

Davis was clearly excited by the surprise, and energised to react spontaneously to the scenario prepared for his character: he is aware of the artifice of the improvisational construct, but understands how it will strengthen his performance. 
Volunteers in some forms of social psychology experiment may also be aware of the artifice of the scenario built by the researchers (unlike the participants in Stanley Milgram and Muzafer Sherif's work, who were unaware of true nature of the experiments). An important example is the work of the eminent social psychologist, Philip Zimbardo, who was responsible for the famous Stanford University Experiment. Zimbardo led a team interested in testing the impact of environment on the behaviour of ordinary educated young men, a study which resulted in a highly influential article in the International Journal of Criminology and Penology, 'Interpersonal Dynamics in a Simulated Prison' (Haney et al, 1973). The team constructed a mock prison in a basement corridor on the Stanford campus and hired volunteers to play the role of either prisoner or guard, for a period of two weeks. The research questions were around the interpersonal dynamics that might develop between the participants in these constrained conditions, in which roles of authority and victim were forced upon the young men by the structures of the exercise. Zimbardo and his team were astonished at the rapidity with which the participants fell into their roles, witnessing the volunteers' extreme out-of-character behaviours, in particular the willingness of the guards to overstep the ethical boundaries that had been established from the start. Within days, some of those in the role of prisoner were experiencing extreme psychological trauma; those playing the Guards were indulging in sadistic forms of degradation - much like the abuse seen in the US military's Abu Ghraib detention centre during the Iraq War. Zimbardo came under pressure to review the experiment on ethical grounds and he curtailed the planned two-week experiment after just six days.

My proposition is that this social psychology experiment was also a form of practicebased filmmaking research (the whole process was recorded on video tape), following a 'Performance-Centred Mode' of creative practice, using improvisation by untrained performers. This becomes more apparent when viewing the feature film based on this research project, The Stanford Prison Experiment (Kyle Patrick Alvares, 2015).

Alvares and his producers identified that the famous experiment was a piece of compelling drama and Zimbardo's character journey was intensely cinematic: a Professor who pursues his research with passion, at first fascinated by the results and at last horrified.

The film's first act shows the research team interviewing volunteers for the experiment who have responded to a newspaper ad. We next see the character Philip Zimbardo, played by Billy Crudup, introduce the experiment to the assembled team: - he addresses his ensemble cast as would a theatre or film director, welcoming them to the project;

- he discusses how Production Design has been deployed to create a sense of authenticity in the prison set;

- he introduces his cast to their costumes - which again is used to help the performers towards a sense of authenticity in their fictional characters;

- And, as would a director setting up an impro, Zimbardo gives a structure within which the performers will work (groundrules include the forbidding of physical violence), but he offers them the freedom to become the characters inside this dramatic space. 
The film is a fictionalised reconstruction of the social psychology experiment, and one of the conceits of the movie is its implicit link between the researchers' methodology and the creative practice of filmmaking. The authenticity of the cinematic representation is strengthened by Philip Zimbardo's role as a coscreenwriter of the film. The film does not deviate far from the historical record of the experiment. The researchers in their 1973 paper describe the briefing of the volunteers:

They were given no other information about what to expect nor instructions about behaviour appropriate for a prisoner role. $(1973,74)$

The volunteers (untrained actors) were clearly being asked to join an improvisational process of devising.

By illuminating the link between filmmaking practice and the work of experimental social psychologists, I hope to contribute to the reflective consideration of practice research by film academics. There has been a trend in this debate that seeks to distance the rationale of filmmaking practice research from the traditions of other disciplines. John Adams has argued that,

The intrinsic and distinctive qualities of $\mathrm{A} / \mathrm{V}$ research practice can sit uncomfortably within the social science and humanities, with their logocentric focus. (2007: 204)

This is certainly overstating a rift between disciplines, as my example of the Stanford Prison Experiment demonstrates. Philip Zimbardo's team, undertaking a 'true randomized experiment' according to the strict logocentric rationale of their social science, adopted the same practice research methods as filmmakers in the Performance-Centred Mode, with remarkable effect. For the developing discipline of film-based practice research, the example shows that we cannot build a notion of difference and exclusivity in opposition to other research traditions. The reality is that there will be a fluidity of methodologies: filmmakers' practice research methods may be borrowed by other disciplines, just as creative practitioners within the academy will learn from established fields.

A further value of contextualising aspects of film practice research in relation to other academic disciplines is that it throws light on a further issue - the debates around categories of research output. We have seen useful discussion about the 'art object' and 'knowledge object' outcomes of practice research, with Desmond Bell emphasising a point of difference between research in creative practice and the social sciences. He describes how,

while an artist's research facilitates their practice, the primary focus of their creative process remains the art object - 'making work' - and not an abstract knowledge object.' (2006, 90)

My comparison of film practice research and experimental social psychology suggests a blurring of this distinction. There is no doubt that social scientists' intention is to reveal a 'knowledge object' through their research, yet we have seen how, in the 
Stanford Prison Experiment, a team of social psychologists in pursuit of a research objective concerning authority in human behaviour produced an 'art object' (the recorded performance of the volunteers) which had profound impact. That art object, however, was not the celebrated achievement of Zimbardo's work at the time: it is the revelations about human reaction to authority, and the shocking knowledge of the vulnerability of social ethics, that are remembered. It required the later intervention of Kyle Patrick Alvares to highlight the 'art object' achieved in the Stanford Prison Experiment.

A film practice researcher's work may reveal an abstract 'knowledge object', as well as generating findings through the 'art object' created in the research process. In contrast to social psychology, we are able to celebrate both forms of research outcome. Another distinction that benefits film research practitioners is that, in this field, the deployment of improvisation methodology can have a more exploratory nature. Philip Zimbardo formulated his hypothesis, that human beings will behave in radically out-of-character ways when pressed into strict authority relationships, and then used the improvisation performed by his volunteers as evidence to prove his assertion. From the perspective of film practice researchers, there is a restrictive quality in this formulation of research methodology. In our discipline, from the initial research intention through to the conclusion, the value of improvisation is that it is the approach most likely to surprise the researcher in the outcomes that it generates. It is not a methodology designed simply to generate conclusive proof of a hypothesis. For filmmaking research practitioners, the potential of improvisation is based on its instability: it enables an exploration towards uncertain conclusions. The documentary-makers Nicholas Humbert and Werner Penzel have written of the characteristics of this methodology in filmmaking practice, in relation to their 1990 film, Step Across the Border:

In improvisation the plan is revealed only at the end. One finds it. $(2015,441)$

Notes on Contributor:

Dominic Lees is Associate Head of Department - Filmmaking, at the University of the West of England (UWE) and is an experienced film director and screenwriter. His directing practice in the UK, Germany, France and Poland has included forty episodes of television drama, short films and the multi-award winning independent feature film, Outlanders (2008). His writing has included regular contributions to film industry publications such as Variety, as well as for scholarly journals. His doctoral research has developed theories of film practice and he was a contributor to the 2017 book, Directing for the Screen (Routledge).

ORCID iD http://orcid.org/0000-0002-3787-3740

\section{References:}

Adams, John. 2007. 'Conceptual smoke and digital mirrors? Issues in audio-visual (A/V) practice research'. Journal of Media Practice, 8(2): 203-219 
Barrett, Estelle, and Barbara Bolt. 2010. Practice as Research: Approaches to Creative Arts Enquiry. London: I.B.Tauris.

Bell, Desmond. 2006. 'Creative film and media practice as research: In pursuit of that obscure object of knowledge'. Journal of Media Practice 7:2, 85-100

Carney, Ray and Leonard, Quart. 2000. The Films of Mike Leigh. London: Cambridge University Press.

Cassidy, Gary. 2018. The rehearsal process of playwright/director Anthony Neilson. PhD diss, University of Reading.

Ferand, Ernst. 1939. Die Improvisation in der Musik. Zurich: Rhein Velag.

Haney, Craig; Banks, Curtis; and Zimbardo, Philip. 1973. 'Interpersonal Dynamics in a Simulated Prison'. International Journal of Criminology and Penology 1973/1: 6997.

Hewstone, Miles and Wolfgang Stroebe. 2001. Introduction to Social Psychology. $3^{\text {rd }}$ ed. Oxford: Blackwell.

Heble, Ajay, and Rebecca Caines, eds. 2015. The Improvisation Studies Reader: Spontaneous Acts. London and New York: Routledge.

Hodgson, John and Ernest Richards. 1974. Improvisation. London: Eyre Methuen.

Humbert, Nicholas and Werner Penzel. 2015. 'Step Across the Border (DVD Liner Notes)'. In The Improvisation Studies Reader: Spontaneous Acts, edited by Ajay Heble and Rebecca Caines, 441. London and New York: Routledge.

Kerouac, J. 'Essentials of Spontaneous Prose'. In The Improvisation Studies Reader: Spontaneous Acts, edited by Ajay Heble and Rebecca Caines, 207-208. London and New York: Routledge.

Lewis, George E. and Benjamin Piekut, eds. 2016. The Oxford Handbook of Critical Improvisational Studies Vol.1. Oxford: Oxford University Press.

Macdonald, Ian W. 2010. “" “...So It's not surprising I'm neurotic”: The Screenwriter and the Screen Idea Work Group'. Journal of Screenwriting 1(1): 45-58

Marchand, Robert. 2015. 'Devising and Directing'. In Devised and Directed by Mike Leigh, edited by Cardinale-Powell, Bryan and Marc DiPaolo. London: Bloomsbury Academic.

Marchand, Robert. 2018. 'CBI Actor and Filmmaker workshops'. Accessed 17 December 2018. http://cbiactorworkshops.com

Nelson, Robin. 2013. Practice as Research in the Arts. Basingstoke: Palgrave Macmillan 
Nettl, Bruno, 2015. 'Thoughts on Improvisation: A Comparative Approach'. In The Improvisation Studies Reader: Spontaneous Acts, edited by Ajay Heble and Rebecca Caines, 70-73. London and New York: Routledge.

Perry, Gina. 2018. The Lost Boys: Inside the Robbers Cave Experiment. Victoria, Australia and London: Scribe.

Pressing, Jeff. 2001/2012. 'Improvisation: methods and models'. In Generative Processes in Music: The Psychology of Performance, Improvisation, and Composition, edited by John A. Sloboda. Oxford: Clarendon Press/Oxford Scholarship Online. DOI:10.1093/acprof:oso/9780198508465.003.0007

Raphael, Amy, ed. 2008. Mike Leigh on Mike Leigh. London: Faber and Faber.

Senje, Siri. 2017. 'Formatting the Imagination: A reflection on screenwriting as a creative process'. Journal of Screenwriting 8(3): 267-285.

Sjöberg, Johannes. 2008. 'Ethnofiction: drama as a creative research practice in ethnographic film', Journal of Media Practice, 9:3, 229-

242. DOI: $10.1386 / j m p r .9 .3 .22911$

Wallace, Rob. 2015. 'Writing Improvisation into Modernism'. In The Improvisation Studies Reader: Spontaneous Acts, edited by Ajay Heble and Rebecca Caines, 187198. London and New York: Routledge. 